\title{
Analysis The Thermal Behavior of Solar Chimney at Varying Parameters
}

\author{
Pratima Patel \\ M. Tech. Scholar \\ RKDF college \\ Bhopal, India \\ pratima.rewa@gmail.com
}

\author{
Manish Sharma \\ Asst. Prof. \\ RKDF college \\ Bhopal, India \\ manish8458@gmail.com
}

\author{
Rajnees Kumar Gedam \\ Asst. Prof. \\ RKDF college \\ Bhopal , India \\ rajneesh.gedam@gmail.com
}

\begin{abstract}
In this paper a computerized analysis of the fluid dynamics was conducted for a solar power plant stacked at collector height $(\mathrm{H} 2=1.85 \mathrm{~m}, 3 \mathrm{~m}, 4 \mathrm{~m}$ and $5 \mathrm{~m})$ with different solar irradiations such as $600 \mathrm{~W} /$ $\mathrm{m} 2,800 \mathrm{~W} / \mathrm{m} 2 \mathrm{~m} 2,900 \mathrm{~W} / \mathrm{m} 2$ and $1000 \mathrm{~W} / \mathrm{m} 2$. The slope of the roof and the radius of curvature of the manifold vary according to the height of the outlet manifold. The intake manifold height is set to $\mathrm{H1}=$ $1.85 \mathrm{~m}$ from a solar cell power plant. The main objective of this work is to study the improvement of efficiency by modifying the design of the solar chimney system by diverging and radial curvature on the roof of the SCPP sensor. From the results, it was observed that the inclination and radius of curvature of the sensor roof had an effect on the efficiency of the sensor and that the efficiency of the sensor was at most $44.92 \%$ when the sensor height $\mathrm{H} 2=5 \mathrm{~m}$.
\end{abstract}

\section{I.INTRODUCTION}

Civilizations have used the energy of the sun for thousands of years. Ancient societies used mirrors and the sun to make fire. Exploring the architecture of early civilizations, one can see that the buildings were designed so that the sun could warm them up and, in turn, provide a heating system to people [1]. From these early beginnings, photovoltaic cells are now used to promote the untapped potential of the sun. Photovoltaic cells, more commonly known as solar cells, were discovered at the end of the 19th century and have been a source of electricity since the 1930s [2]. Individual panels can be used to power motor vehicles, but large solar cell fields can be used for power generation centers.

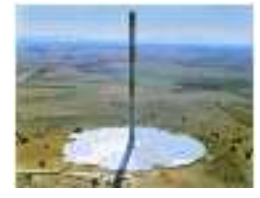

Figure 1 Proto-type Solar Tower in Manzanares, Spain
The solar storage system is designed to generate hot air under the roof of the greenhouse sensor. The heated air rises through the buoyancy through a high structure in the middle of the sensor, called the solar chimney. The hot air drives during the ascent an air turbine that is arranged in the chimney to produce electricity.

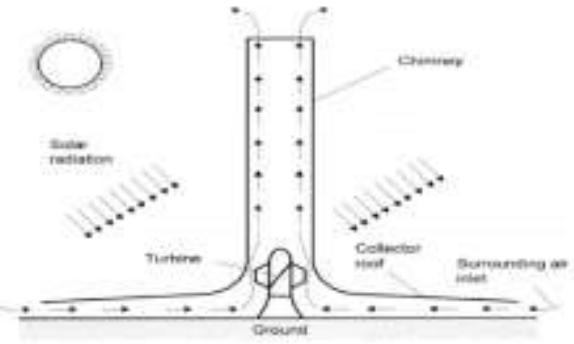

Fig 2: Solar chimney power configuration Several definitions can therefore be specified. The radiation of the beam is incident radiation from the direction of the sun. It means that it has not been dispersed. Radiation is the one that is useful for concentrated solar energy (CSP). Its intensity depends strongly on the orientation of the surface on which it is collected. As a result, the sensors must be aligned with the CSP technology during the day to maximize the received radiation. The orientation of the beam radiation can be calculated at any time of the season (for each latitude and longitude) of the Earth. This is due to geometric relationships, which will not be described later in this work

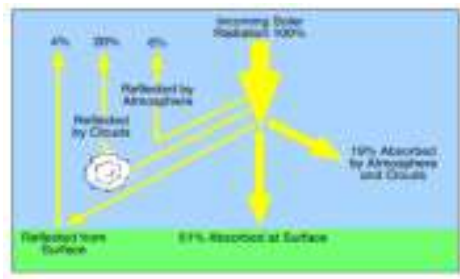

Fig 3: Attenuation of the incoming solar radiation 


\section{II.LITERATURE REVIEW}

Aakash Hassan, Majid Ali \& Adeel Waqas [01] In this study, parametric fluid parametric (CFD) analysis of a solar cell power plant was performed to illustrate the effects of the inclination of the sensor and the cutting angle on the performance of the Manzanares prototype. The numerical models were constructed with solar charge models, DO (discrete ordinate) and RNG k-3 turbulence. First, the CFD simulation results were validated by comparing the experimental data of the Manzanares prototype. Thus, based on the robustness of the numerical methods applied, several numerical simulations have been made with different inclinations of the deflection angles of the collector and of the chimney to improve the performance of the solar chimney.

Ehsan Gholamalizadeh \& Man-Hoe Kim [04] In this paper, we present a study of dynamic numerical calculation of fluids on a solar chimney system with inclined roof. A three-dimensional model that uses the turbulence closure $\mathrm{R}$ G (normalization group) $\mathrm{k} \_\varepsilon$ is simulated. The non-gray discrete orderly radiation model is used to implement the radiation transfer equation. To simulate solar radiation, the solar beam tracking algorithm is used. In a parametric study, the influence of the sensor configuration on the performance of the Manzanares power plant is shown.

Nadia Saifia al el. [15] In this work, a detailed mathematical simulation and an experimental study of the air flow in the solar chimneys are studied. Several experimental tests have been performed on the solar chimney; The choice depends on the design parameters and the thermal performance for different geometric configurations. Experimental tests show that the field velocities in the chimney are influenced by the width of the channel and the angle of inclination of the chimney. Therefore, this article has conducted research to determine the effects of the inclination on household performance in the province of Ouargla, Algeria.

Atit Koonsrisuk \& Tawit Chitsomboon [11] The solar chimney system is a system that promises the production of electricity from free solar energy. In this study, a solar collector, a chimney and a turbine are theoretically modeled together and the iteration techniques are performed to solve the mathematical model obtained. The results are confirmed by the measurements of a true physical installation. In addition, the model is used to predict the performance characteristics of large-scale commercial sunshades, indicating that the size of the plant, the turbine drop pressure factor and the solar heat flux are important parameters for the performance of commercial sunshades. Performance improvement.

\section{III.OBJECTIVE}

There are following objective of the present work.

1. The main objective of the present work to perform computational fluid dynamic analysis to enhance the collector efficiency by changing the design of solar chimney power plant.

2. To perform the CFD analysis on solar chimney using different collector height of solar chimney power plant.

3. To compare the various results obtained from CFD analysis of various design of solar chimney power plant.

4. To validate the collector efficiency with base paper and also check the collector efficiency with modified design.

\section{IV.METHODOLOGY}

\section{Algorithm used for Computational fluid} dynamics analysis:

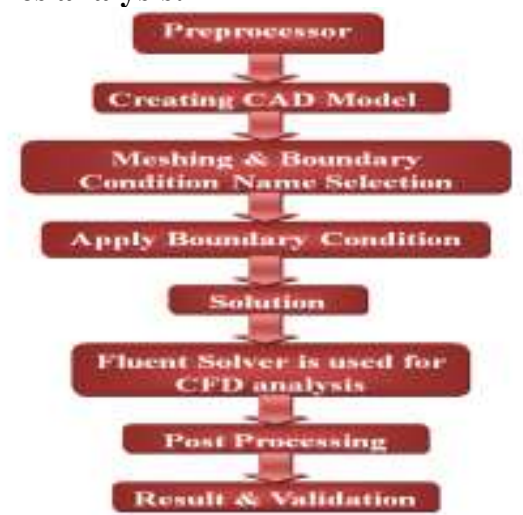

Figure 4 : Algorithm used for Computational fluid dynamics analysis

\section{1) Boundary condition:}

1. To determine the temperature distribution inside the solar chimney power plant need to on energy equation.

2. Defining of material property, set working fluid as air and chimney walls is metal sheet with thermal conductivity of $0.6 \mathrm{~W} / \mathrm{m}^{-} \mathrm{K} \& 16.27 \mathrm{~W} / \mathrm{m}^{-} \mathrm{K}$, top of collector is covered with transparent glass and the earth surface is considered as soil material.

3. For the outlet boundary condition the gauge pressure needs to be set as zero because the flow of air inside the solar chimney is atmospheric.

4. Solar radiations were used on collector roof of solar chimney power plant vary with time and taken as 850 $\mathrm{w} / \mathrm{m}^{2}$.

5. The Fluent solver is used for CFD analysis.

2) Computational fluid dynamics analysis for solar chimney power plant for with collector height $\mathrm{H}_{1}=\mathrm{H}_{2}$ $=1.85 \mathrm{~m}$ (zero slope) at $600 \mathrm{~W} / \mathrm{m} 2$ solar radiation:

The maximum temperature $316 \mathrm{~K}$ has been recorded and the temperature difference of 16 degree has been observed.

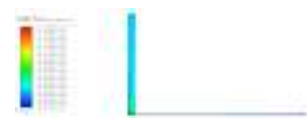


Figure 5: Temperature distribution on solar chimney power plant for with collector height $\mathrm{H}_{1}=\mathrm{H}_{2}=1.85 \mathrm{~m}$ (zero slope) at $600 \mathrm{~W} / \mathrm{m} 2$ solar radiation

The maximum velocity of $10.4 \mathrm{~m} / \mathrm{sec}$ has been observed.

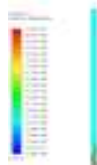

Figure 6 : Velocity distribution on solar chimney power plant for with collector height $\mathrm{H}_{1}=\mathrm{H}_{2}=1.85 \mathrm{~m}$ (zero slope) at $600 \mathrm{~W} / \mathrm{m} 2$ solar radiation

3 Computational fluid dynamics analysis for solar chimney power plant for with collector height $\mathbf{H}_{1}=\mathbf{H}_{2}$ $=1.85 \mathrm{~m}$ (zero slope) at $800 \mathrm{~W} / \mathrm{m} 2$ solar radiation:

The maximum temperature $322 \mathrm{~K}$ has been recorded and the temperature difference of 22 degree has been observed.

The maximum velocity of $10.4 \mathrm{~m} / \mathrm{sec}$ has been observed.

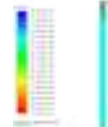

Figure 7: Velocity distribution on solar chimney power plant 4 Computational fluid dynamics analysis for solar chimney power plant for with collector height $\mathbf{H}_{1}=\mathbf{H}_{2}$ $=1.85 \mathrm{~m}$ (zero slope) at $850 \mathrm{~W} / \mathrm{m} 2$ solar radiation:

The maximum temperature $324 \mathrm{~K}$ has been recorded and the temperature difference of 24 degree has been observed.

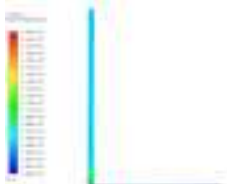

Figure 8: Temperature distribution on solar chimney power plant for with collector height $\mathrm{H}_{1}=\mathrm{H}_{2}=1.85 \mathrm{~m}$ (zero slope) at $850 \mathrm{~W} / \mathrm{m} 2$ solar radiation

The maximum velocity of $10.4 \mathrm{~m} / \mathrm{sec}$ has been observed.

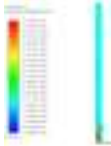

Figure 9: Velocity distribution on solar chimney power plant for with collector height $\mathrm{H}_{1}=\mathrm{H}_{2}=1.85 \mathrm{~m}$ (zero slope) at $850 \mathrm{~W} / \mathrm{m} 2$ solar radiation

5 Computational fluid dynamics analysis for solar chimney power plant for with collector height $\mathbf{H}_{1}=\mathbf{H}_{2}$ $=1.85 \mathrm{~m}$ (zero slope) at $900 \mathrm{~W} / \mathrm{m} 2$ solar radiation:

The maximum temperature $325 \mathrm{~K}$ has been recorded and the temperature difference of 25 degree has been observed.

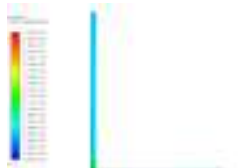

Figure 10: Temperature distribution on solar chimney power plant for with collector height $\mathrm{H}_{1}=\mathrm{H}_{2}=1.85 \mathrm{~m}$ (zero slope) at $900 \mathrm{~W} / \mathrm{m} 2$ solar radiation

The maximum velocity of $10.4 \mathrm{~m} / \mathrm{sec}$ has been observed.

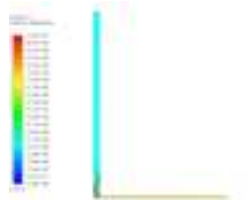

Figure 11: Velocity distribution on solar chimney power plant for with collector height $\mathrm{H}_{1}=\mathrm{H}_{2}=1.85 \mathrm{~m}$ (zero slope) at $900 \mathrm{~W} / \mathrm{m} 2$ solar radiation

6 Computational fluid dynamics analysis for solar chimney power plant for with collector height $\mathbf{H}_{1}=\mathbf{H}_{2}$ $=1.85 \mathrm{~m}$ (zero slope) at $1000 \mathrm{~W} / \mathrm{m} 2$ solar radiation:

The maximum temperature $327 \mathrm{~K}$ has been recorded and the temperature difference of 27 degree has been observed.

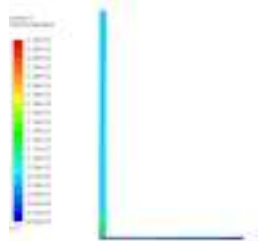

Figure 12: Temperature distribution on solar chimney power plant for with collector height $\mathrm{H}_{1}=\mathrm{H}_{2}=1.85 \mathrm{~m}$ (zero slope) at $1000 \mathrm{~W} / \mathrm{m} 2$ solar radiation

The maximum velocity of $10.4 \mathrm{~m} / \mathrm{sec}$ has been observed.

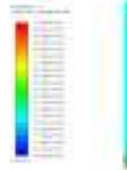

Figure 13: Velocity distribution on solar chimney power plant for with collector height $\mathrm{H}_{1}=\mathrm{H}_{2}=1.85 \mathrm{~m}$ (zero slope) at $1000 \mathrm{~W} / \mathrm{m} 2$ solar radiation

7 Computational fluid dynamics analysis for solar chimney power plant for with collector height $\mathrm{H}_{2}=\mathbf{3}$ $\mathrm{m}$ at $600 \mathrm{~W} / \mathrm{m}^{2}$ solar radiation:

The maximum temperature $319 \mathrm{~K}$ has been recorded and the temperature difference of 19 degree has been observed.

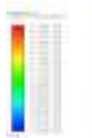

Figure 14: Temperature distribution on solar chimney power plant for with collector height $\mathrm{H}_{2}=3 \mathrm{~m}$ at $600 \mathrm{~W} / \mathrm{m}^{2}$ solar radiation

The computational fluid dynamics analysis has been performed on solar chimney power plant for with collector height $\mathrm{H}_{2}=3 \mathrm{~m}$ at $600 \mathrm{~W} / \mathrm{m}^{2}$ solar radiation, to get velocity distribution of air inside the solar chimney. The maximum velocity of $8.01 \mathrm{~m} / \mathrm{sec}$ has been observed.

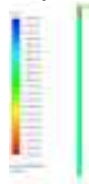

Figure 15: Velocity distribution on solar chimney power plant for with collector height $\mathrm{H}_{2}=3 \mathrm{~m}$ at $600 \mathrm{~W} / \mathrm{m}^{2}$ solar radiation 
8 Computational fluid dynamics analysis for solar chimney power plant for with collector height $\mathrm{H}_{2}=3$ $\mathrm{m}$ at $800 \mathrm{~W} / \mathrm{m}^{2}$ solar radiation:

The computational fluid dynamics analysis has been performed on solar chimney power plant for with collector height $\mathrm{H}_{2}=3 \mathrm{~m}$ at $800 \mathrm{~W} / \mathrm{m}^{2}$ solar radiation, to get temperature distribution over the solar chimney. The maximum temperature $326 \mathrm{~K}$ has been recorded and the temperature difference of 26 degree has been observed.

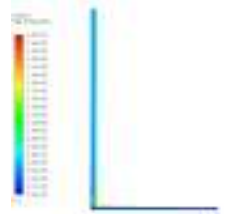

Figure 16: Temperature distribution on solar chimney power plant for with collector height $\mathrm{H}_{2}=3 \mathrm{~m}$ at $800 \mathrm{~W} / \mathrm{m}^{2}$ solar radiation

The computational fluid dynamics analysis has been performed on solar chimney power plant for with collector height $\mathrm{H}_{2}=3 \mathrm{~m}$ at $800 \mathrm{~W} / \mathrm{m}^{2}$ solar radiation, to get velocity distribution of air inside the solar chimney. The maximum velocity of $8.01 \mathrm{~m} / \mathrm{sec}$ has been observed.

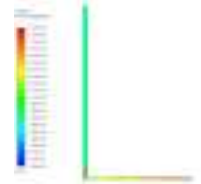

Figure 17: Velocity distribution on solar chimney power plant for with collector height $\mathrm{H}_{2}=3 \mathrm{~m}$ at $800 \mathrm{~W} / \mathrm{m}^{2}$ solar radiation

9 Computational fluid dynamics analysis for solar chimney power plant for with collector height $\mathrm{H}_{2}=3$ $\mathrm{m}$ at $850 \mathrm{~W} / \mathrm{m}^{2}$ solar radiation:

The computational fluid dynamics analysis has been performed on solar chimney power plant for with collector height $\mathrm{H}_{2}=3 \mathrm{~m}$ at $850 \mathrm{~W} / \mathrm{m}^{2}$ solar radiation, to get temperature distribution over the solar chimney. The maximum temperature $324 \mathrm{~K}$ has been recorded and the temperature difference of 24 degree has been observed.

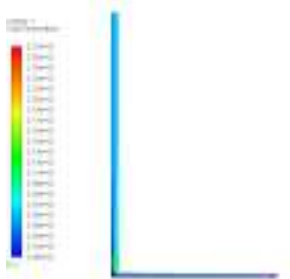

Figure 18: Temperature distribution on solar chimney power plant for with collector height $\mathrm{H}_{2}=3 \mathrm{~m}$ at $850 \mathrm{~W} / \mathrm{m}^{2}$ solar radiation

The computational fluid dynamics analysis has been performed on solar chimney power plant for with collector height $\mathrm{H}_{2}=3 \mathrm{~m}$ at $850 \mathrm{~W} / \mathrm{m}^{2}$ solar radiation, to get velocity distribution of air inside the solar chimney. The maximum velocity of $10.4 \mathrm{~m} / \mathrm{sec}$ has been observed.

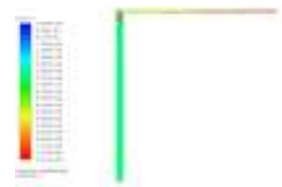

Figure 19: Velocity distribution on solar chimney power plant for with collector height $\mathrm{H}_{2}=3 \mathrm{~m}$ at $850 \mathrm{~W} / \mathrm{m}^{2}$ solar radiation

10 Computational fluid dynamics analysis for solar chimney power plant for with collector height $\mathbf{H}_{2}=3$ $\mathrm{m}$ at $900 \mathrm{~W} / \mathrm{m}^{2}$ solar radiation:

The computational fluid dynamics analysis has been performed on solar chimney power plant for with collector height $\mathrm{H}_{2}=3 \mathrm{~m}$ at $900 \mathrm{~W} / \mathrm{m}^{2}$ solar radiation, to get temperature distribution over the solar chimney. The maximum temperature $329 \mathrm{~K}$ has been recorded and the temperature difference of 29 degree has been observed.

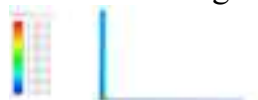

Figure 20: Temperature distribution on solar chimney power plant for with collector height $\mathrm{H}_{2}=3 \mathrm{~m}$ at $900 \mathrm{~W} / \mathrm{m}^{2}$ solar radiation

The computational fluid dynamics analysis has been performed on solar chimney power plant for with collector height $\mathrm{H}_{2}=3 \mathrm{~m}$ at $900 \mathrm{~W} / \mathrm{m}^{2}$ solar radiation, to get velocity distribution of air inside the solar chimney. The maximum velocity of $8.01 \mathrm{~m} / \mathrm{sec}$ has been observed.

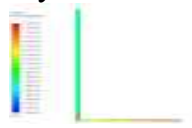

Figure 4.26 : Velocity distribution on solar chimney power plant for with collector height $\mathrm{H}_{2}=3 \mathrm{~m}$ at $900 \mathrm{~W} / \mathrm{m}^{2}$ solar radiation

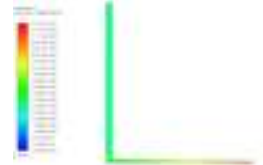

Figure 4.34 : Velocity distribution on solar chimney power plant for with collector height $\mathrm{H} 2=4 \mathrm{~m}$ at $600 \mathrm{~W} / \mathrm{m}^{2}$ solar radiation

11 Computational fluid dynamics analysis for solar chimney power plant for with collector height $\mathrm{H} 2=4$ $\mathrm{m}$ at $800 \mathrm{~W} / \mathrm{m}^{2}$ solar radiation:

The maximum temperature $326 \mathrm{~K}$ has been recorded and the temperature difference of 26 degree has been observed.

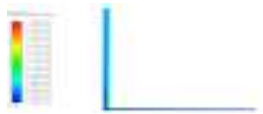

Figure 4.35 : Temperature distribution on solar chimney power plant for with collector height $\mathrm{H} 2=4 \mathrm{~m}$ at $800 \mathrm{~W} / \mathrm{m}^{2}$ solar radiation

The maximum velocity of $8 \mathrm{~m} / \mathrm{sec}$ has been observed.

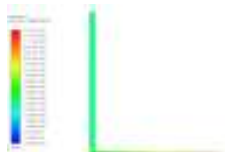

Figure 4.36 : Velocity distribution on solar chimney power plant for with collector height $\mathrm{H} 2=4 \mathrm{~m}$ at $800 \mathrm{~W} / \mathrm{m}^{2}$ solar radiation 
12 Computational fluid dynamics analysis for solar chimney power plant for with collector height $\mathrm{H} 2=4$ $\mathrm{m}$ at $850 \mathrm{~W} / \mathrm{m}^{2}$ solar radiation:

The maximum temperature $330 \mathrm{~K}$ has been recorded and the temperature difference of 30 degree has been observed.

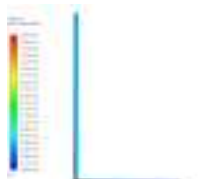

Figure 4.37 : Temperature distribution on solar chimney power plant for with collector height $\mathrm{H} 2=4 \mathrm{~m}$ at $850 \mathrm{~W} / \mathrm{m}^{2}$ solar radiation

The computational fluid dynamics analysis has been performed on solar chimney power plant for with collector height $\mathrm{H} 2=4 \mathrm{~m}$ at $850 \mathrm{~W} / \mathrm{m}^{2}$ solar radiation, to get velocity distribution of air inside the solar chimney. The maximum velocity of $8 \mathrm{~m} / \mathrm{sec}$ has been observed.

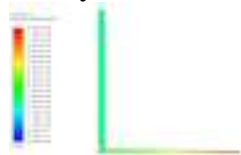

Figure 4.38 : Velocity distribution on solar chimney power plant for with collector height $\mathrm{H} 2=4 \mathrm{~m}$ at $850 \mathrm{~W} / \mathrm{m}^{2}$ solar radiation

13 Computational fluid dynamics analysis for solar chimney power plant for with collector height $\mathrm{H} 2=4$ $\mathrm{m}$ at $900 \mathrm{~W} / \mathrm{m}^{2}$ solar radiation:

The computational fluid dynamics analysis has been performed on solar chimney power plant for with collector height $\mathrm{H} 2=4 \mathrm{~m}$ at $900 \mathrm{~W} / \mathrm{m}^{2}$ solar radiation, to get temperature distribution over the solar chimney. The maximum temperature $329 \mathrm{~K}$ has been recorded and the temperature difference of 29 degree has been observed.

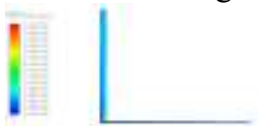

Figure 21: Temperature distribution on solar chimney power plant for with collector height $\mathrm{H} 2=4 \mathrm{~m}$ at $900 \mathrm{~W} / \mathrm{m}^{2}$ solar radiation

The computational fluid dynamics analysis has been performed on solar chimney power plant for with collector height $\mathrm{H} 2=4 \mathrm{~m}$ at $900 \mathrm{~W} / \mathrm{m}^{2}$ solar radiation, to get velocity distribution of air inside the solar chimney. The maximum velocity of $8.01 \mathrm{~m} / \mathrm{sec}$ has been observed.

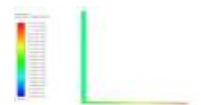

Figure 22: Velocity distribution on solar chimney power plant for with collector height $\mathrm{H} 2=4 \mathrm{~m}$ at $900 \mathrm{~W} / \mathrm{m}^{2}$ solar radiation

14 Computational fluid dynamics analysis for solar chimney power plant for with collector height $\mathrm{H} 2=4$ $\mathrm{m}$ at $1000 \mathrm{~W} / \mathrm{m}^{2}$ solar radiation:

The maximum temperature $333 \mathrm{~K}$ has been recorded and the temperature difference of 33 degree has been observed.

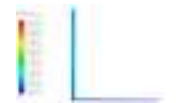

Figure 23: Temperature distribution on solar chimney power plant for with collector height $\mathrm{H} 2=4 \mathrm{~m}$ at $1000 \mathrm{~W} / \mathrm{m}^{2}$ solar radiation

The maximum velocity of $8.01 \mathrm{~m} / \mathrm{sec}$ has been observed.

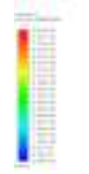

Figure 24: Velocity distribution on solar chimney power plant for with collector height $\mathrm{H} 2=4 \mathrm{~m}$ at $1000 \mathrm{~W} / \mathrm{m}^{2}$ solar radiation

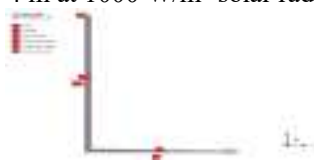

Figure 25: different boundaries of solar chimney power plant with collector height $\mathrm{H} 2=5 \mathrm{~m}$

15 Computational fluid dynamics analysis for solar chimney power plant for with collector height $\mathbf{H 2}=5$ $\mathrm{m}$ at $600 \mathrm{~W} / \mathrm{m}^{2}$ solar radiation:

The maximum temperature $321 \mathrm{~K}$ has been recorded and the temperature difference of 21 degree has been observed.

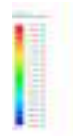

Figure 26: Temperature distribution on solar chimney power plant for with collector height $\mathrm{H} 2=5 \mathrm{~m}$ at $600 \mathrm{~W} / \mathrm{m}^{2}$ solar radiation

The maximum velocity of $8.01 \mathrm{~m} / \mathrm{sec}$ has been observed.

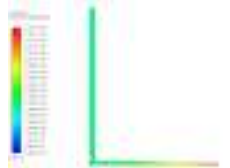

Figure 27: Velocity distribution on solar chimney power plant for with collector height $\mathrm{H} 2=5 \mathrm{~m}$ at $600 \mathrm{~W} / \mathrm{m}^{2}$ solar radiation

16 Computational fluid dynamics analysis for solar chimney power plant for with collector height $\mathbf{H} 2=5$ $\mathrm{m}$ at $800 \mathrm{~W} / \mathrm{m}^{2}$ solar radiation:

The maximum temperature $328 \mathrm{~K}$ has been recorded and the temperature difference of 28 degree has been observed.

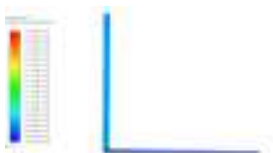

Figure 28: Temperature distribution on solar chimney power plant for with collector height $\mathrm{H} 2=5 \mathrm{~m}$ at $800 \mathrm{~W} / \mathrm{m}^{2}$ solar radiation

The maximum velocity of $8.01 \mathrm{~m} / \mathrm{sec}$ has been observed.

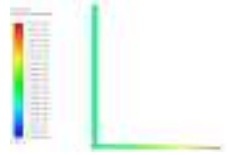

Figure 29: Velocity distribution on solar chimney power plant for with collector height $\mathrm{H} 2=5 \mathrm{~m}$ at $800 \mathrm{~W} / \mathrm{m}^{2}$ solar radiation 
17 Computational fluid dynamics analysis for solar chimney power plant for with collector height $\mathrm{H} 2=5$ $\mathrm{m}$ at $850 \mathrm{~W} / \mathrm{m}^{2}$ solar radiation:

The maximum temperature $331 \mathrm{~K}$ has been recorded and the temperature difference of 31 degree has been observed.

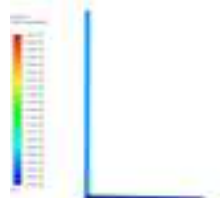

Figure 30: Temperature distribution on solar chimney power plant for with collector height $\mathrm{H} 2=5 \mathrm{~m}$ at $850 \mathrm{~W} / \mathrm{m}^{2}$ solar radiation

The maximum velocity of $8 \mathrm{~m} / \mathrm{sec}$ has been observed.

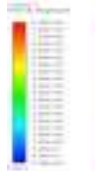

Figure31: Velocity distribution on solar chimney power plant for with collector height $\mathrm{H} 2=5 \mathrm{~m}$ at $850 \mathrm{~W} / \mathrm{m}^{2}$ solar radiation

18 Computational fluid dynamics analysis for solar chimney power plant for with collector height $\mathrm{H} 2=5$ $\mathrm{m}$ at $900 \mathrm{~W} / \mathrm{m}^{2}$ solar radiation:

The maximum temperature $332 \mathrm{~K}$ has been recorded and the temperature difference of 32 degree has been observed.

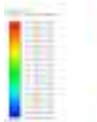

Figure 32: Temperature distribution on solar chimney power plant for with collector height $\mathrm{H} 2=5 \mathrm{~m}$ at $900 \mathrm{~W} / \mathrm{m}^{2}$ solar radiation The maximum velocity of $8.01 \mathrm{~m} / \mathrm{sec}$ has been observed.

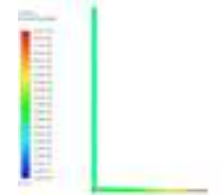

Figure 33: Velocity distribution on solar chimney power plant for with collector height $\mathrm{H} 2=5 \mathrm{~m}$ at $900 \mathrm{~W} / \mathrm{m}^{2}$ solar radiation

19 Computational fluid dynamics analysis for solar chimney power plant for with collector height $\mathrm{H} 2=5$ $\mathrm{m}$ at $1000 \mathrm{~W} / \mathrm{m}^{2}$ solar radiation:

The maximum temperature $335 \mathrm{~K}$ has been recorded and the temperature difference of 35 degree has been observed.

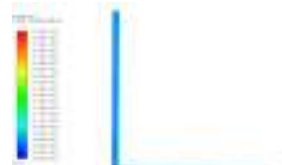

Figure 34: Temperature distribution on solar chimney power plant for with collector height $\mathrm{H} 2=5 \mathrm{~m}$ at $1000 \mathrm{~W} / \mathrm{m}^{2}$ solar radiation The maximum velocity of $8.01 \mathrm{~m} / \mathrm{sec}$ has been observed.

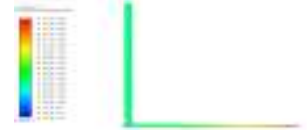

Figure 35: Velocity distribution on solar chimney power plant for with collector height $\mathrm{H} 2=5 \mathrm{~m}$ at $1000 \mathrm{~W} / \mathrm{m}^{2}$ solar radiation

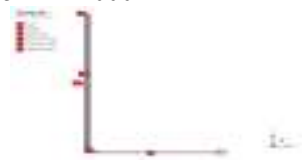

Figure 36: different boundaries of solar chimney power plant plant including curvature on collector with height of $\mathrm{H} 2=1.85 \mathrm{~m}$

20 CFD analysis of solar chimney power plant including curvature on collector with height of $\mathrm{H} 2=$ $1.85 \mathrm{~m}$ at $600 \mathrm{w} / \mathrm{m}^{2}$ solar radiation:

The maximum temperature $348 \mathrm{~K}$ has been recorded and the temperature difference of 48 degree has been observed.

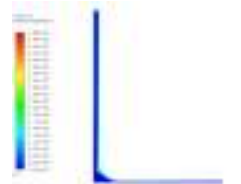

Figure 37: Temperature distribution on solar chimney power plant including curvature on collector with height of $\mathrm{H} 2=1.85 \mathrm{~m}$ at $600 \mathrm{w} / \mathrm{m} 2$ solar radiation

The maximum velocity of $8.66 \mathrm{~m} / \mathrm{sec}$ has been observed.

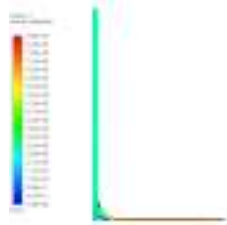

Figure 38: Velocity distribution on solar chimney power plant including curvature on collector with height of $\mathrm{H} 2=1.85 \mathrm{~m}$ at $600 \mathrm{w} / \mathrm{m} 2$ solar radiation

21 CFD analysis of solar chimney power plant including curvature on collector with height of $\mathbf{H 2}=$ $1.85 \mathrm{~m}$ at $800 \mathrm{w} / \mathrm{m}^{2}$ solar radiation:

The maximum temperature $364 \mathrm{~K}$ has been recorded and the temperature difference of 64 degree has been observed.

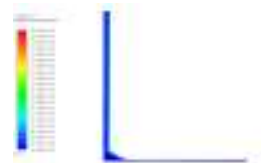

Figure 39: Temperature distribution on solar chimney power plant including curvature on collector with height of $\mathrm{H} 2=1.85 \mathrm{~m}$ at $800 \mathrm{w} / \mathrm{m} 2$ solar radiation

The maximum velocity of $8.66 \mathrm{~m} / \mathrm{sec}$ has been observed.

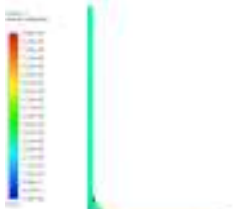

Figure 40: Velocity distribution on solar chimney power plant including curvature on collector with height of $\mathrm{H} 2=1.85 \mathrm{~m}$ at $800 \mathrm{w} / \mathrm{m} 2$ solar radiation

22 CFD analysis of solar chimney power plant including curvature on collector with height of $\mathrm{H} 2=$ $1.85 \mathrm{~m}$ at $900 \mathrm{w} / \mathrm{m}^{2}$ solar radiation:

The maximum temperature $372 \mathrm{~K}$ has been recorded and the temperature difference of 72 degree has been 
observed.

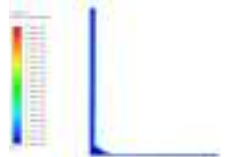

Figure 41: Temperature distribution on solar chimney power plan including curvature on collector with height of $\mathrm{H} 2=1.85 \mathrm{~m}$ at $900 \mathrm{w} / \mathrm{m} 2$ solar radiation

The maximum velocity of $8.66 \mathrm{~m} / \mathrm{sec}$ has been observed.

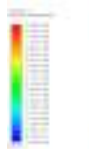

Figure 42: Velocity distribution on solar chimney power plant including curvature on collector with height of $\mathrm{H} 2=1.85 \mathrm{~m}$ at $900 \mathrm{w} / \mathrm{m} 2$ solar radiation

23 CFD analysis of solar chimney power plant including curvature on collector with height of $\mathrm{H} 2=$ $1.85 \mathrm{~m}$ at $1000 \mathrm{w} / \mathrm{m}^{2}$ solar radiation:

The maximum temperature $381 \mathrm{~K}$ has been recorded and the temperature difference of 81 degree has been observed.

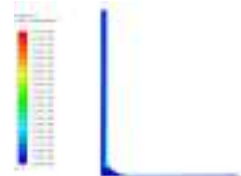

Figure 43: Temperature distribution on solar chimney power plan including curvature on collector with height of $\mathrm{H} 2=1.85 \mathrm{~m}$ at 1000 $\mathrm{w} / \mathrm{m} 2$ solar radiation

The maximum velocity of $8.66 \mathrm{~m} / \mathrm{sec}$ has been observed.

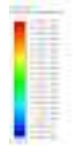

Figure 44: Velocity distribution on solar chimney power plant including curvature on collector with height of $\mathrm{H} 2=1.85 \mathrm{~m}$ at $1000 \mathrm{w} / \mathrm{m} 2$ solar radiation

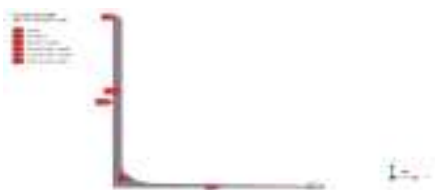

Figure 45: different boundaries of solar chimney power plant plant including curvature on collector with height of $\mathrm{H} 2=3 \mathrm{~m}$

24 CFD analysis of solar chimney power plant including curvature on collector with height of $\mathbf{H} 2=3$ $\mathrm{m}$ at $600 \mathrm{w} / \mathrm{m}^{2}$ solar radiation:

The maximum temperature $334 \mathrm{~K}$ has been recorded and the temperature difference of 34 degree has been observed.

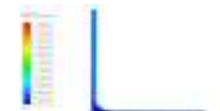

Figure 46: Temperature distribution on solar chimney power plant including curvature on collector with height of $\mathrm{H} 2=3 \mathrm{~m}$ at $600 \mathrm{w} / \mathrm{m} 2$ solar radiation

The maximum velocity of $8.01 \mathrm{~m} / \mathrm{sec}$ has been observed.
Figure 47: Velocity distribution on solar chimney power plant including curvature on collector with height of $\mathrm{H} 2=3 \mathrm{~m}$ at $600 \mathrm{w} / \mathrm{m} 2$ solar radiation

25 CFD analysis of solar chimney power plant including curvature on collector with height of $\mathrm{H} 2=3$ $\mathrm{m}$ at $800 \mathrm{w} / \mathrm{m}^{2}$ solar radiation:

The maximum temperature $345 \mathrm{~K}$ has been recorded and the temperature difference of 45 degree has been observed.

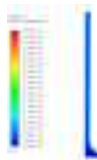

Figure 48: Temperature distribution on solar chimney power plant including curvature on collector with height of $\mathrm{H} 2=3 \mathrm{~m}$ at $800 \mathrm{w} / \mathrm{m} 2$ solar radiation

The maximum velocity of $8.01 \mathrm{~m} / \mathrm{sec}$ has been observed.

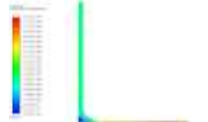

Figure 49: Velocity distribution on solar chimney power plant including curvature on collector with height of $\mathrm{H} 2=3 \mathrm{~m}$ at $800 \mathrm{w} / \mathrm{m} 2$ solar radiation

26 CFD analysis of solar chimney power plant including curvature on collector with height of $\mathrm{H} 2=3$ $\mathrm{m}$ at $900 \mathrm{w} / \mathrm{m}^{2}$ solar radiation:

The maximum temperature $348 \mathrm{~K}$ has been recorded and the temperature difference of 48 degree has been observed.

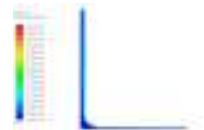

Figure 50: Temperature distribution on solar chimney power plant including curvature on collector with height of $\mathrm{H} 2=3 \mathrm{~m}$ at $900 \mathrm{w} / \mathrm{m} 2$ solar radiation

The maximum velocity of $8.01 \mathrm{~m} / \mathrm{sec}$ has been observed.

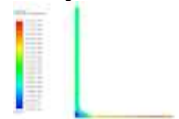

Figure 51: Velocity distribution on solar chimney power plant including curvature on collector with height of $\mathrm{H} 2=3 \mathrm{~m}$ at $900 \mathrm{w} / \mathrm{m} 2$ solar radiation

27 CFD analysis of solar chimney power plant including curvature on collector with height of $\mathbf{H 2}=3$ $\mathrm{m}$ at $1000 \mathrm{w} / \mathrm{m}^{2}$ solar radiation:

The maximum temperature $348 \mathrm{~K}$ has been recorded and the temperature difference of 48 degree has been observed.

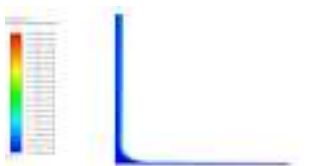

Figure 52: Temperature distribution on solar chimney power plant including curvature on collector with height of $\mathrm{H} 2=3 \mathrm{~m}$ at $1000 \mathrm{w} / \mathrm{m} 2$ solar radiation 
The maximum velocity of $8.01 \mathrm{~m} / \mathrm{sec}$ has been observed.

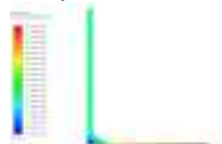

Figure 56: Velocity distribution on solar chimney power plant including curvature on collector with height of $\mathrm{H} 2=3 \mathrm{~m}$ at $1000 \mathrm{w} / \mathrm{m} 2$ solar radiation

28 CFD analysis of solar chimney power plant including curvature on collector with height of $\mathrm{H} 2=$ $4 \mathrm{~m}$ at $600 \mathrm{w} / \mathrm{m}^{2}$ solar radiation:

The maximum temperature $339 \mathrm{~K}$ has been recorded and the temperature difference of 39 degree has been observed.

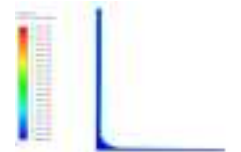

Figure 57: Temperature distribution on solar chimney power plant including curvature on collector with height of $\mathrm{H} 2=4 \mathrm{~m}$ at $600 \mathrm{w} / \mathrm{m} 2$ solar radiation

The maximum velocity of $8.01 \mathrm{~m} / \mathrm{sec}$ has been observed.

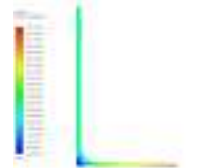

Figure 58: Velocity distribution on solar chimney power plant including curvature on collector with height of $\mathrm{H} 2=4 \mathrm{~m}$ at $600 \mathrm{w} / \mathrm{m} 2$ solar radiation

29 CFD analysis of solar chimney power plant including curvature on collector with height of $\mathrm{H} 2=$ $4 \mathrm{~m}$ at $800 \mathrm{w} / \mathrm{m}^{2}$ solar radiation:

The maximum temperature $352 \mathrm{~K}$ has been recorded and the temperature difference of 52 degree has been observed.

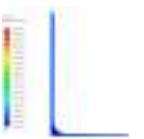

Figure 59: Temperature distribution on solar chimney power plant including curvature on collector with height of $\mathrm{H} 2=4 \mathrm{~m}$ at $800 \mathrm{w} / \mathrm{m} 2$ solar radiation

The maximum velocity of $8.01 \mathrm{~m} / \mathrm{sec}$ has been observed.

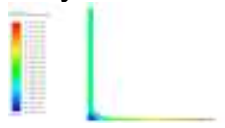

Figure 60: Velocity distribution on solar chimney power plant including curvature on collector with height of $\mathrm{H} 2=4 \mathrm{~m}$ at $800 \mathrm{w} / \mathrm{m} 2$ solar radiation

30 CFD analysis of solar chimney power plant including curvature on collector with height of $\mathrm{H} 2=$ $4 \mathrm{~m}$ at $900 \mathrm{w} / \mathrm{m}^{2}$ solar radiation:

The maximum temperature $358 \mathrm{~K}$ has been recorded and the temperature difference of 58 degree has been observed.

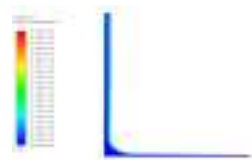

Figure 61: Temperature distribution on solar chimney power plant including curvature on collector with height of $\mathrm{H} 2=4 \mathrm{~m}$ at $900 \mathrm{w} / \mathrm{m} 2$ solar radiation

The maximum velocity of $8.01 \mathrm{~m} / \mathrm{sec}$ has been observed. 32 CFD analysis of solar chimney power plant including curvature on collector with height of $\mathrm{H} 2=$ $4 \mathrm{~m}$ at $1000 \mathrm{w} / \mathrm{m}^{2}$ solar radiation:

The maximum temperature $365 \mathrm{~K}$ has been recorded and the temperature difference of 65 degree has been observed.

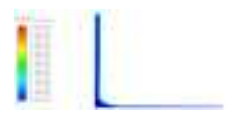

Figure 62: Temperature distribution on solar chimney power plant including curvature on collector with height of $\mathrm{H} 2=4 \mathrm{~m}$ at $1000 \mathrm{w} / \mathrm{m} 2$ solar radiation

The maximum velocity of $8.01 \mathrm{~m} / \mathrm{sec}$ has been observed.

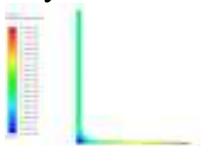

Figure 63: Velocity distribution on solar chimney power plant including curvature on collector with height of $\mathrm{H} 2=4 \mathrm{~m}$ at $1000 \mathrm{w} / \mathrm{m} 2$ solar radiation

33 CFD analysis of solar chimney power plant including curvature on collector with height of $\mathbf{H 2}=$ $5 \mathrm{~m}$ at $600 \mathrm{w} / \mathrm{m}^{2}$ solar radiation:

The maximum temperature $321 \mathrm{~K}$ has been recorded and the temperature difference of 21 degree has been observed.

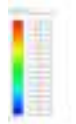

Figure 64: Temperature distribution on solar chimney power plant including curvature on collector with height of $\mathrm{H} 2=5 \mathrm{~m}$ at $600 \mathrm{w} / \mathrm{m} 2$ solar radiation

The maximum velocity of $8.01 \mathrm{~m} / \mathrm{sec}$ has been observed.

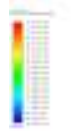

Figure 65: Velocity distribution on solar chimney power plant including curvature on collector with height of $\mathrm{H} 2=5 \mathrm{~m}$ at $600 \mathrm{w} / \mathrm{m} 2$ solar radiation

34 CFD analysis of solar chimney power plant including curvature on collector with height of $\mathrm{H} 2=$ $5 \mathrm{~m}$ at $800 \mathrm{w} / \mathrm{m}^{2}$ solar radiation:

The maximum temperature $328 \mathrm{~K}$ has been recorded and the temperature difference of 28 degree has been observed.

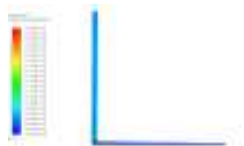

Figure 66: Temperature distribution on solar chimney power plant including curvature on collector with height of $\mathrm{H} 2=5 \mathrm{~m}$ at $800 \mathrm{w} / \mathrm{m} 2$ solar radiation

The maximum velocity of $8.01 \mathrm{~m} / \mathrm{sec}$ has been observed. 


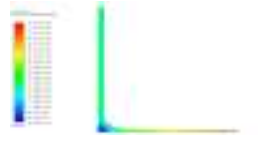

Figure 67: Velocity distribution on solar chimney power plant including curvature on collector with height of $\mathrm{H} 2=5 \mathrm{~m}$ at $800 \mathrm{w} / \mathrm{m} 2$ solar $\operatorname{rad} 31$ CFD analysis of solar chimney power plant including curvature on collector with height of $\mathrm{H2}=$ $5 \mathrm{~m}$ at $1000 \mathrm{w} / \mathrm{m}^{2}$ solar radiation:

The maximum temperature $355 \mathrm{~K}$ has been recorded and the temperature difference of 55 degree has been observed.

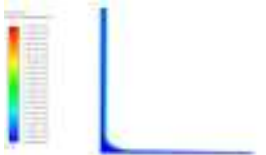

Figure 68: Temperature distribution on solar chimney power plan including curvature on collector with height of $\mathrm{H} 2=5 \mathrm{~m}$ at $1000 \mathrm{w} / \mathrm{m} 2$ solar radiation

The maximum velocity of $8.01 \mathrm{~m} / \mathrm{sec}$ has been observed.

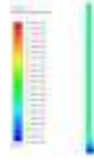

Figure 69: Velocity distribution on solar chimney power plant including curvature on collector with height of $\mathrm{H} 2=5 \mathrm{~m}$ at $1000 \mathrm{w} / \mathrm{m} 2$ solar radiation

\section{Result}

\section{V.RESULT AND DISCUSSION}

In the present work roof inclination of collector is vary by changing the outlet collector height $\left(\mathrm{H}_{2}=1.85 \mathrm{~m}, 3 \mathrm{~m}, 4 \mathrm{~m}\right.$ $\& 5 \mathrm{~m}$ ) and the inlet collector height is fixed as $\mathrm{H}_{1}=1.85 \mathrm{~m}$ of solar chimney power plant. There are various results obtained by computational fluid dynamics analysis and mathematical analysis which are explained.

Numerical calculation:-

Used parameters are

Chimney height $=194.5 \mathrm{~m}$

Chimney diameter $=10 \mathrm{~m}$

Collector diameter $=244 \mathrm{~m}$

Distance from ground to the collector roof $\mathrm{H} 1=1.85 \mathrm{~m}$

\& $\mathrm{H} 2=3 \mathrm{~m}, 4 \mathrm{~m} \& 5 \mathrm{~m}$

Efficiency of turbine $=80 \%$

Specific heat of the air $1.006 \mathrm{kj} / \mathrm{kg}-\mathrm{k}$

Solar radiation ranging from 600 to $1000 \mathrm{w} / \mathrm{m} 2$

Ambient temperature $=300 \mathrm{k}$

Wind velocity at inlet $=8 \mathrm{~m} / \mathrm{sec}$

Area of chimney: $A_{c h}=\frac{\pi}{4} \times$ Chimney Dai $^{2}$

Area of collector: $A_{\text {coll }}=\frac{\pi}{4} \times$ Collector Dia ${ }^{2}$

\section{Chimney efficiency:}

The air heated in the collector and after passing through the turbine blades, will be entered in the chimney. Hot air flow obtained from the collector is converted into kinetic and potential energy, which causes convection currents in the chimney and drops pressure in the wind turbine.

$$
\begin{gathered}
\eta_{c h}=\frac{g \times H_{c}}{c_{p} \times T_{a}} \\
\eta_{c h}=\frac{9.81 \times 194.5}{100.5 \times 27} \\
\eta_{c h}=70.3 \%
\end{gathered}
$$

\section{Turbine efficiency:}

Axial wind turbine is used in Solar Chimney Power Plant, which is located at the base of the chimney. The turbine converts kinetic energy of the air current into useful mechanical rotary work. Efficiency of a turbine can be taken as 0.8 :

$$
\eta_{t}=1-\frac{V_{2}}{2 C_{p} \Delta T \eta_{c h}}
$$

\section{Collector Efficiency:}

According to reference Schlaich (1996), collector efficiency is ratio of the amount of heat obtained from air to the available heat from the sun irradiance, which is defined as:

$$
\eta_{\text {coll }}=\frac{\dot{m} \times c_{p} \times \Delta T}{G \times A_{\text {coll }}}
$$

The total efficiency of the system is defined by

$$
\eta_{\text {scpp }}=\eta_{\text {coll }} \times \eta_{c h} \times \eta_{t}
$$

Total power can be calculated as follows:

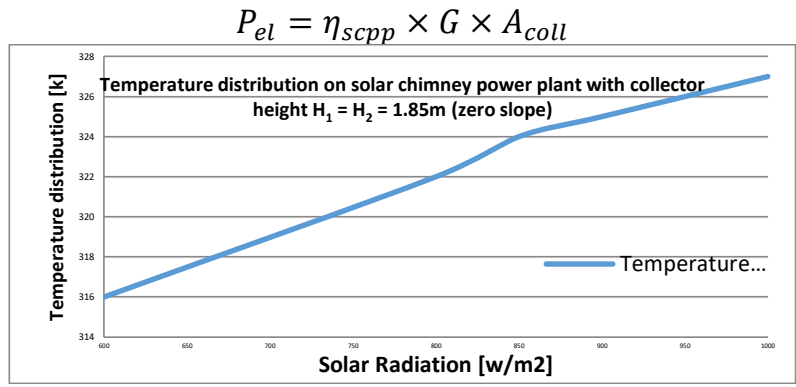

Figure 70: Temperature distribution on solar chimney power plant with collector height $\mathrm{H}_{1}=\mathrm{H}_{2}=1.85 \mathrm{~m}$ (zero slope)

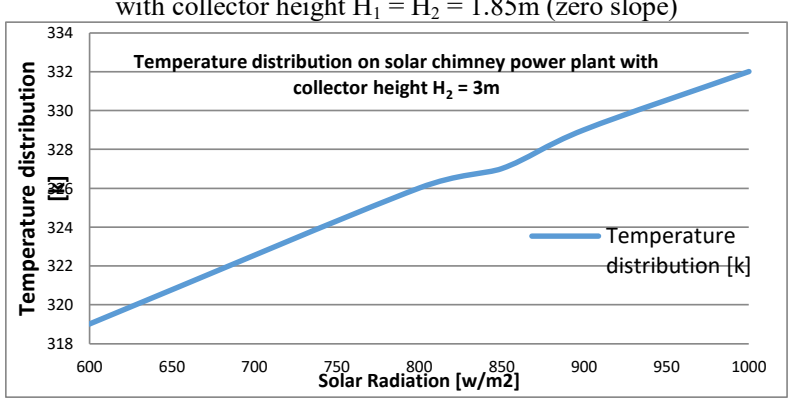

Figure 71: Temperature distribution on solar chimney power plant with collector height $\mathrm{H}_{2}=3 \mathrm{~m}$ 


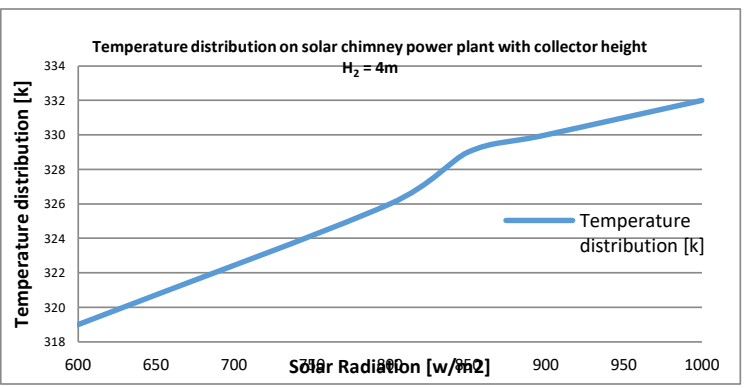

Figure 72: Temperature distribution on solar chimney power plant with collector height $\mathrm{H}_{2}=4 \mathrm{~m}$

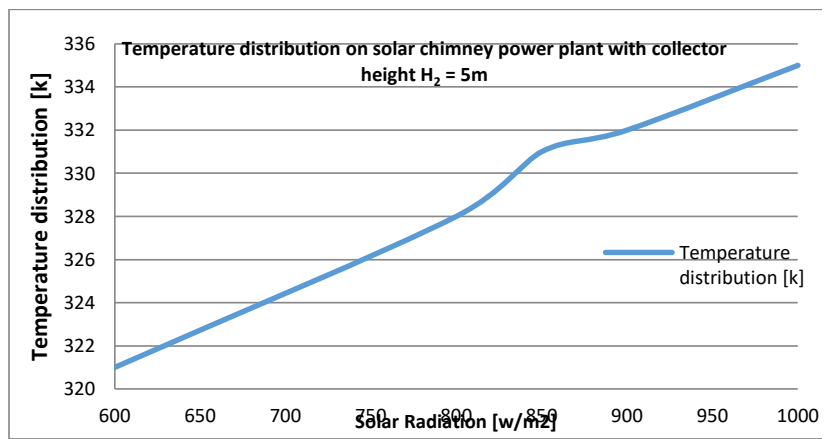

Figure 73: Temperature distribution on solar chimney power plant with collector height $\mathrm{H}_{2}=5 \mathrm{~m}$

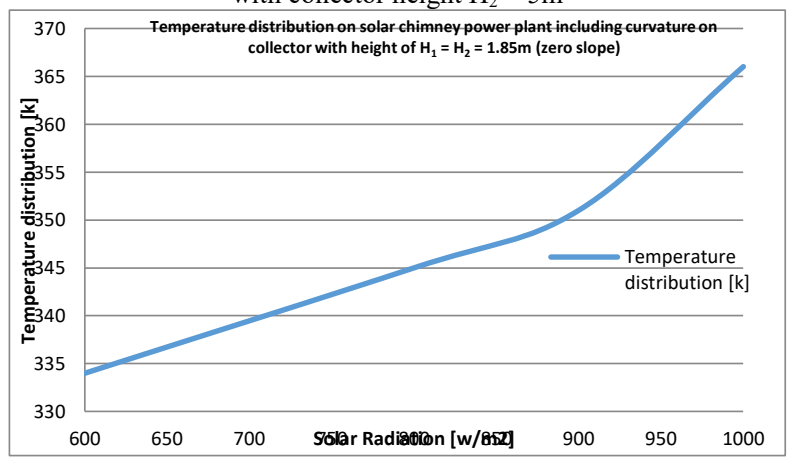

Figure 74: Temperature distribution on solar chimney power plant including curvature on collector with height of $\mathrm{H}_{1}=\mathrm{H}_{2}=1.85 \mathrm{~m}$ (zero slope)

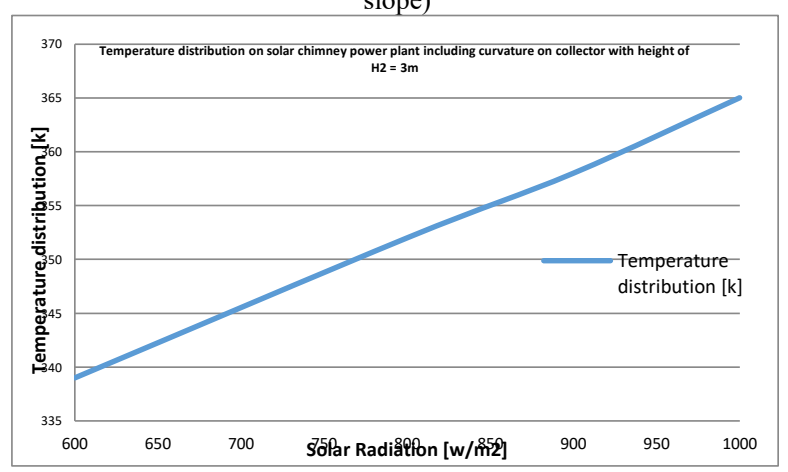

Figure 75: Temperature distribution on solar chimney power plant cluding curvature on collector with height of $\mathrm{H} 2=3 \mathrm{~m}$

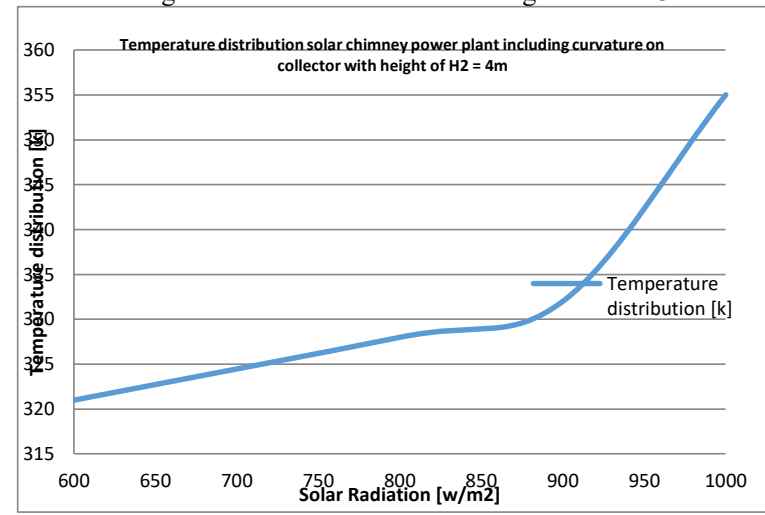

Figure 76: Temperature distribution solar chimney power plant including curvature on collector with height of $\mathrm{H} 2=4 \mathrm{~m}$

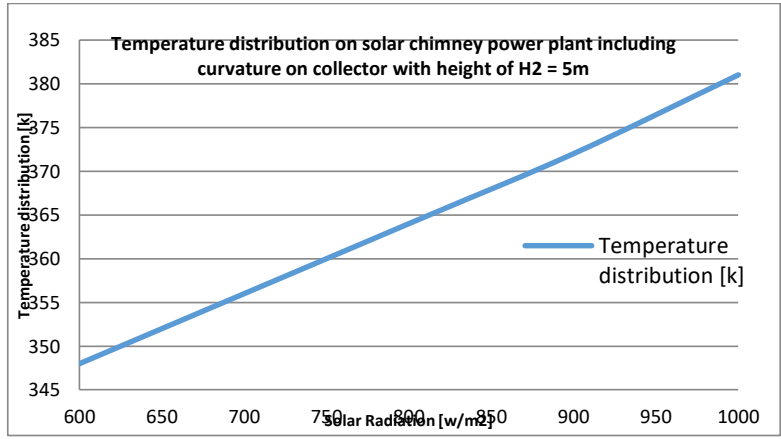

Figure 5.8 : Temperature distribution on solar chimney power plant including curvature on collector with height of $\mathrm{H} 2=5 \mathrm{~m}$

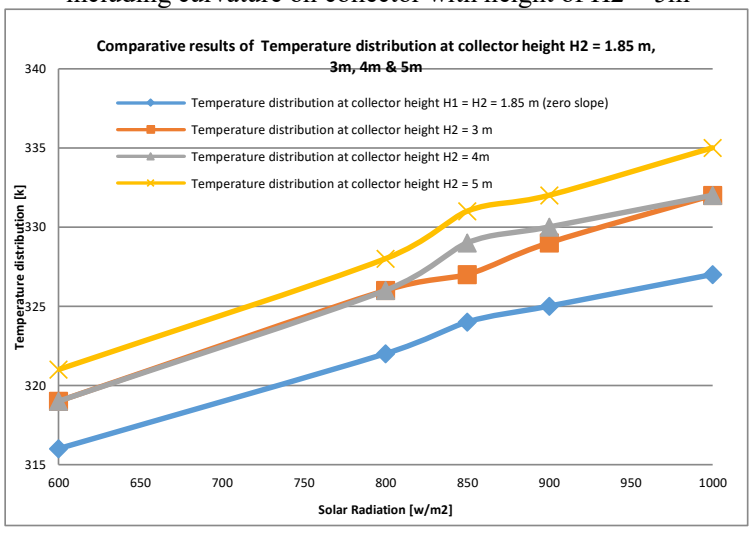

Figure 77: Comparative results of Temperature distribution at collector height $\mathrm{H}_{2}=1.85 \mathrm{~m}, 3 \mathrm{~m}, 4 \mathrm{~m} \& 5 \mathrm{~m}$ 


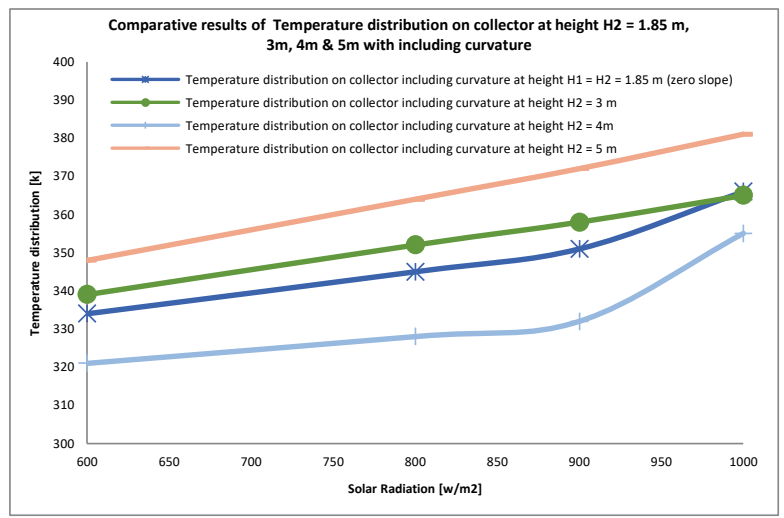

Figure 78: Comparative results of Temperature distribution on collector at height $\mathrm{H}_{2}=1.85 \mathrm{~m}, 3 \mathrm{~m}, 4 \mathrm{~m} \& 5 \mathrm{~m}$ with including curvature

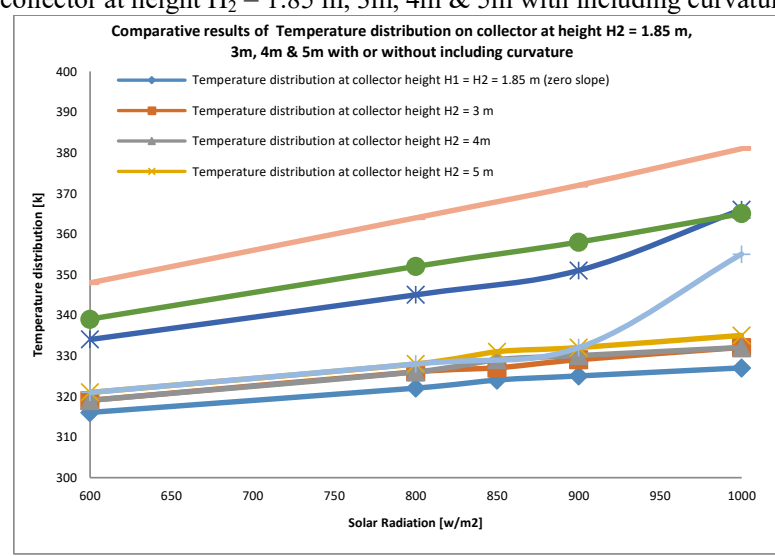

Figure 79: Comparative results of Temperature distribution on collector at height $\mathrm{H}_{2}=1.85 \mathrm{~m}, 3 \mathrm{~m}, 4 \mathrm{~m} \& 5 \mathrm{~m}$ with or without including curvature

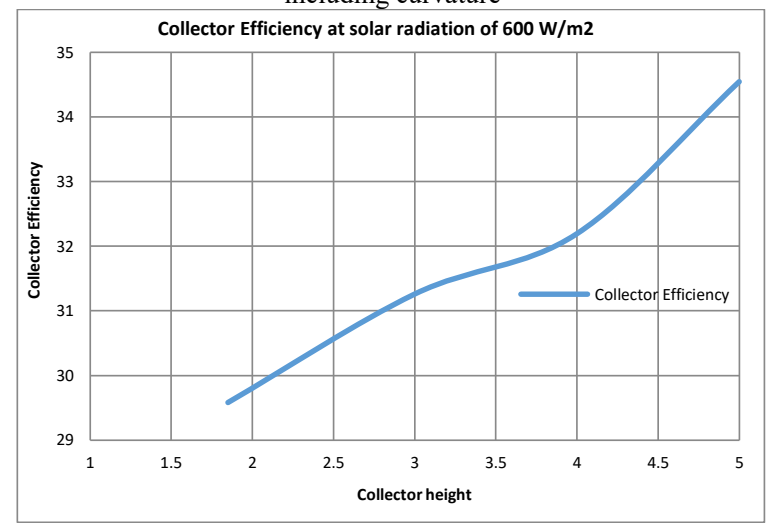

Figure 80: Collector Efficiency at solar radiation of $600 \mathrm{~W} / \mathrm{m}^{2}$ Collector Efficiency at solar radiation of $800 \mathrm{~W} / \mathrm{m} 2$

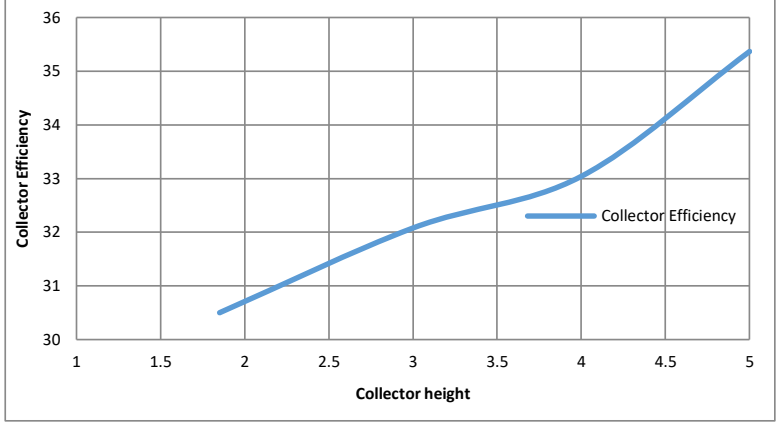

Figure 81: Collector Efficiency at solar radiation of $800 \mathrm{~W} / \mathrm{m}^{2}$

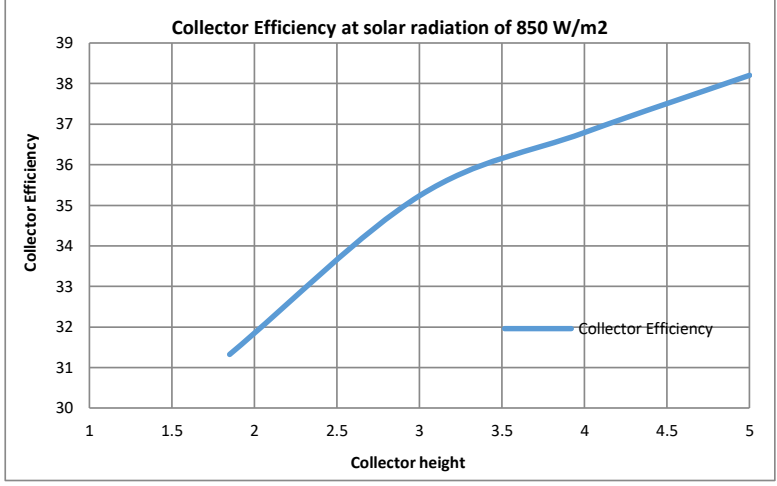

Figure 82 : Collector Efficiency at solar radiation of $850 \mathrm{~W} / \mathrm{m}^{2}$

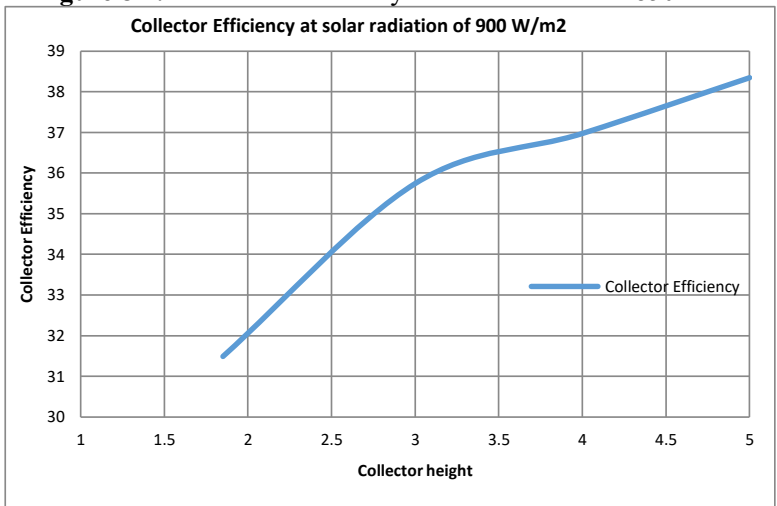

Figure 83: Collector Efficiency at solar radiation of $900 \mathrm{~W} / \mathrm{m}^{2}$

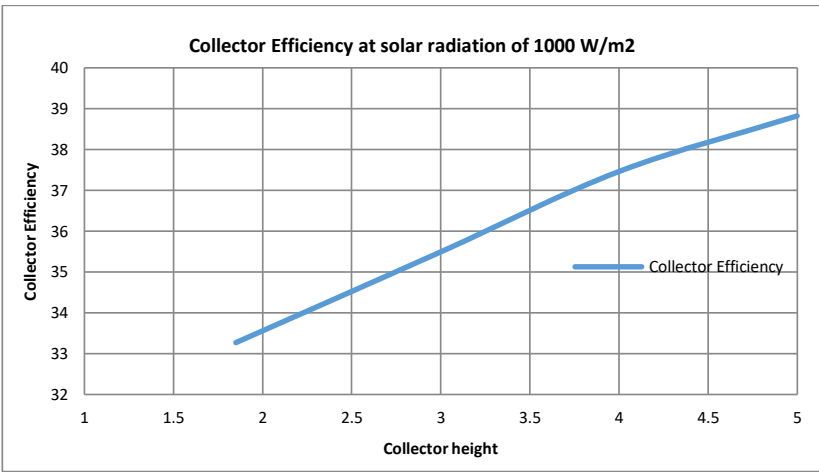


Figure 84: Collector Efficiency at solar radiation of $1000 \mathrm{~W} / \mathrm{m}^{2}$

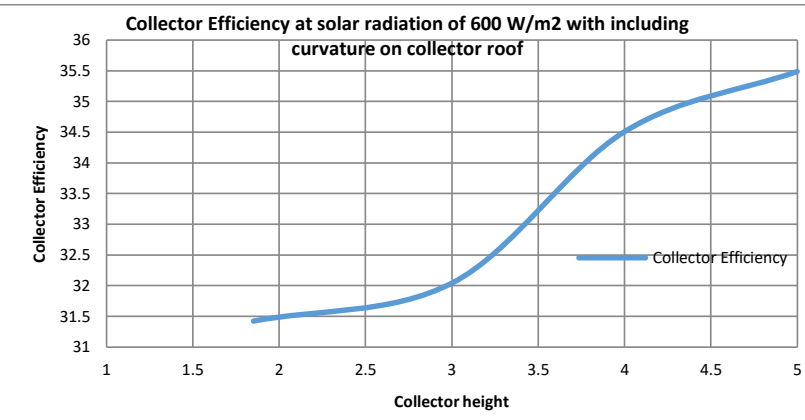

Figure 85: Collector Efficiency at solar radiation of $600 \mathrm{~W} / \mathrm{m}^{2}$ with including curvature on collector roof

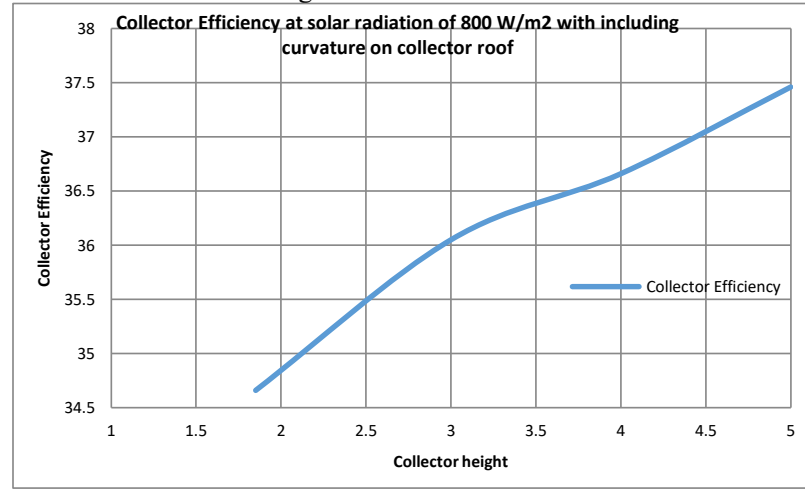

Figure 86: Collector Efficiency at solar radiation of $800 \mathrm{~W} / \mathrm{m}^{2}$ with including curvature on collector roof

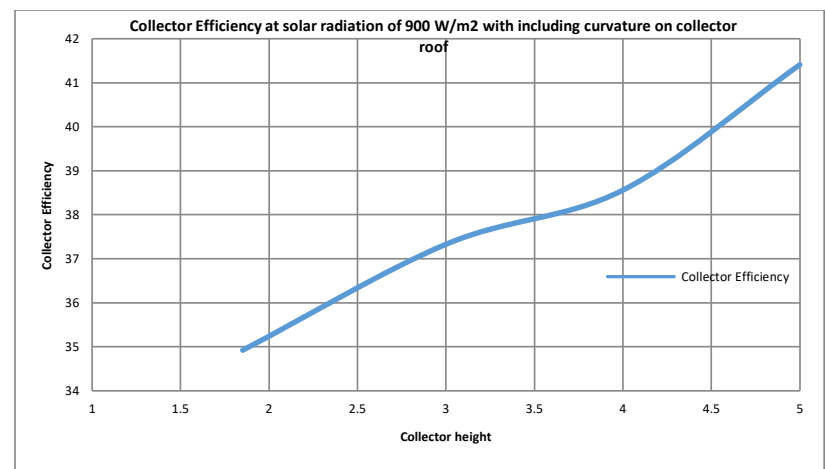

Figure 87: Collector Efficiency at solar radiation of $900 \mathrm{~W} / \mathrm{m}^{2}$ with including curvature on collector roof

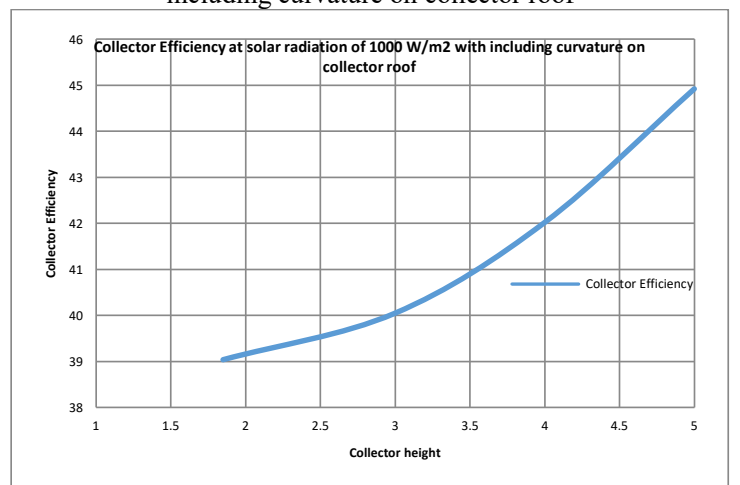

Figure 88: Collector Efficiency at solar radiation of $1000 \mathrm{~W} / \mathrm{m}^{2}$ with including curvature on collector roof

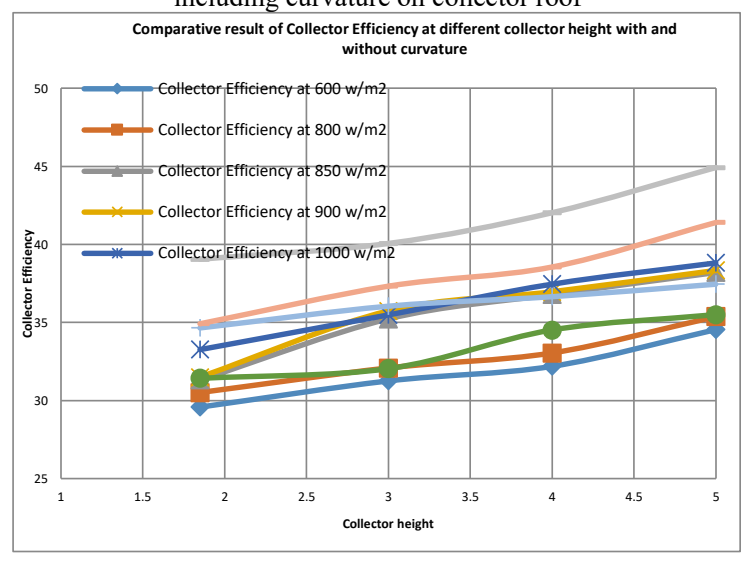

Figure 89: Comparative result of Collector Efficiency at different collector height with and without curvature

\section{CONCLUSION}

In the present work a computerized analysis of the fluid dynamics was conducted for a solar power plant stacked at collector height $(\mathrm{H} 2=1.85 \mathrm{~m}, 3 \mathrm{~m}, 4 \mathrm{~m}$ and $5 \mathrm{~m})$ with different solar irradiations such as $600 \mathrm{~W} / \mathrm{m} 2,800 \mathrm{~W} /$ $\mathrm{m} 2,850 \mathrm{~W} / \mathrm{m} 2 . \mathrm{m} 2,900 \mathrm{~W} / \mathrm{m} 2$ and $1000 \mathrm{~W} / \mathrm{m} 2$. The slope of the roof and the radius of curvature of the manifold vary according to the height of the outlet manifold. The intake manifold height is set to $\mathrm{H} 1=1.85$ $\mathrm{m}$ from a solar cell power plant. The following final points are drawn from this work.

Fluid dynamics analysis was performed on a stacked power plant with collector height $\mathrm{H} 1=\mathrm{H} 2=1.85 \mathrm{~m}$ (zero waste) at $600 \mathrm{~W} / \mathrm{m} 600 \mathrm{~W} / \mathrm{m} 2,800 \mathrm{~W} / \mathrm{m} 2,850 \mathrm{~W} /$ $\mathrm{m} 2,900 \mathrm{~W} / \mathrm{m} 2 . \mathrm{m} 2$ and $1000 \mathrm{~W} / \mathrm{m} 2$ of solar radiation. The temperature distribution in the solar system was observed between $316 \mathrm{~K}$ and $327 \mathrm{~K}$ with a temperature increase of 16-27 degrees and the sensor efficiency increased from $29.58 \%$ to $33.27 \%$.

The computer's fluid dynamics analysis was performed on a stacked power plant with $\mathrm{H} 2$ collector height $=3$ but 600 $\mathrm{W} / \mathrm{m} 600 \mathrm{~W} / \mathrm{m} 2,800 \mathrm{~W} / \mathrm{m} 2,850 \mathrm{~W} / \mathrm{m} 2,900 \mathrm{~W} / \mathrm{m} 2$ and $1000 \mathrm{~W} / \mathrm{m} 2$ of solar radiation. The temperature distribution in the solar plant was observed in a range from $319 \mathrm{~K}$ to $332 \mathrm{~K}$ with a temperature increase of 19 to 32 degrees and the efficiency of the sensor increased from $31.26 \%$ to $35.48 \%$.

Dynamic dynamic fluid analysis was performed on a stacked power plant with $\mathrm{H} 2$ collector height $=4$ but 600 $\mathrm{W} / \mathrm{m} 600 \mathrm{~W} / \mathrm{m} 2,800 \mathrm{~W} / \mathrm{m} 2,850 \mathrm{~W} / \mathrm{m} 2,900 \mathrm{~W} / \mathrm{m} 2$ and $1000 \mathrm{~W} / \mathrm{m} 2$ of solar radiation. The temperature distribution within the solar cell stack was observed in a range from $319 \mathrm{~K}$ to $332 \mathrm{~K}$ with a temperature increase of 
19 to 32 degrees and the sensor efficiency increased from 32.20 to $37,46 \%$.

Dynamic dynamic fluid analysis was performed on a stacked power plant with $\mathrm{H} 2$ collector height $=5$ but 600 $\mathrm{W} / \mathrm{m} 600 \mathrm{~W} / \mathrm{m} 2,800 \mathrm{~W} / \mathrm{m} 2,850 \mathrm{~W} / \mathrm{m} 2,900 \mathrm{~W} / \mathrm{m} 2$ and $1000 \mathrm{~W} / \mathrm{m} 2$ of solar radiation. The temperature distribution in the solar system was observed between $321 \mathrm{~K}$ and $335 \mathrm{~K}$ with a temperature increase of 21 to 35 degrees and the sensor efficiency increased from $34.55 \%$ to $38.82 \%$.

CFD analysis was performed on a solar plant with a curvature on the main collector $\mathrm{H} 1=\mathrm{H} 2=1.85 \mathrm{~m}$ (zero offset) at $600 \mathrm{~W} / \mathrm{m} 2,800 \mathrm{~W} / \mathrm{m} 2,900 \mathrm{~W} / \mathrm{m} 2$ and 1000 $\mathrm{W} / \mathrm{m} 2$. M2 of solar radiation performed. The temperature distribution in the solar power plant was observed between $334 \mathrm{~K}$ and $366 \mathrm{~K}$ with a temperature increase of 34-66 degrees and the sensor efficiency increased from $31.42 \%$ to $39.04 \%$.

CFD analysis was performed on a photovoltaic system stacked with a curvature on the collector with a height of $\mathrm{H} 2=3 \mathrm{~m}$ and solar radiation of $600 \mathrm{~W} / \mathrm{m} 2,800 \mathrm{~W} / \mathrm{m} 2$, $900 \mathrm{~W} / \mathrm{m} 2$ and $1000 \mathrm{~W} / \mathrm{m} 2$. The temperature distribution in the solar system was observed between $339 \mathrm{~K}$ and $365 \mathrm{~K}$ with a temperature increase from 39 to 65 degrees and the sensor efficiency increased from $32.04 \%$ to $40.05 \%$.

The CFD analysis was performed on a photovoltaic system stacked with a curvature on the collector with a height of $\mathrm{H} 2=4 \mathrm{~m}$ with a solar radiation of $600 \mathrm{~W} / \mathrm{m} 2$, $800 \mathrm{~W} / \mathrm{m} 2,900 \mathrm{~W} / \mathrm{m} 2$ and $1000 \mathrm{~W} / \mathrm{m} 2$. The temperature distribution in the solar system was observed between $321 \mathrm{~K}$ and $355 \mathrm{~K}$ with a temperature increase of 21 to 55 degrees and the sensor efficiency increased from $34.51 \%$ to $42.02 \%$.

The CFD analysis was performed on a stacked photovoltaic system with a curvature of the collector with a height of $\mathrm{H} 2=5 \mathrm{~m}$ with solar irradiation of $600 \mathrm{~W} / \mathrm{m} 2$, $800 \mathrm{~W} / \mathrm{m} 2,900 \mathrm{~W} / \mathrm{m} 2$ and $1000 \mathrm{~W} / \mathrm{m} 2$. The temperature distribution in the solar plant was observed between $348 \mathrm{~K}$ and $381 \mathrm{~K}$ with a temperature increase of 48-81 degrees and the sensor efficiency increased from $35.49 \%$ to $44.92 \%$.

From the above conclusion, it can be seen that the inclination and radius of curvature of the sensor roof influence the efficiency of the sensor and that the sensor efficiency is maximal when the height of the sensor $\mathrm{H} 2=$ $5 \mathrm{~m}$.
[1] Aakash Hassan, Majid Ali \& Adeel Waqas "Numerical investigation on performance of solar chimney power plant by varying collector slope and chimney diverging angle" Energy 142 (2018) 411-425.

[2] Ahmed Ayadi at el. "Experimental and numerical analysis of the collector roof height effect on the solar chimney performance" Renewable Energy 115 (2018) 649-662.

[3] Siyang Hu \& Dennis Y.C. Leung "Mathematical modelling of the performance of a solar chimney power plant with divergent chimneys" 1st International Conference on Energy and Power, ICEP2016, 14-16 December 2016, RMIT University, Melbourne, Australia, Energy Procedia 110 (2017) 440 - 445.

[4] Ehsan Gholamalizadeh \& Man-Hoe Kim "CFD (computational fluid dynamics) analysis of a solar-chimney power plant with inclined collector roof" Energy 107 (2016) 661-667.

[5] Xinping Zhou \& Yangyang Xu "Review Solar updraft tower power generation" Solar Energy 128 (2016) 95-125.

[6] Nima Fathi Seyed, Sobhan Aleyasin \& Peter Vorobie "On the form of the power equation for modeling solar chimney power plant systems" Preprint submitted to Elsevier, August 27, 2015.

[7] John Kaiser Calautit at el. "CFD Simulation and Optimisation of a Low Energy Ventilation and Cooling System" Computation 2015, 3, 128-149; ISSN 2079-3197, doi:10.3390/computation3020128.

[8] Attig Bahar F at el. "A NUMERICAL study of solar chimney power plants in Tunisia" Tunisia-Japan Symposium: R\&D of Energy and Material Sciences, Journal of Physics: Conference Series 596 (2015) 012006.

[9] Sandeep K. Patel, Deepak Prasad \& M. Rafiuddin Ahmed "Computational studies on the effect of geometric parameters on the performance of a solar chimney power plant" Energy Conversion and Management 77 (2014) 424-431.

[10] Atit Koonsrisuk \& Tawit Chitsomboon "Effects of flow area changes on the potential of solar chimney power plants" Energy 51 (2013) 400-406.

\section{REFERENCES}

